\title{
The immature stages of Labrundinia tenata (Diptera: Chironomidae: Tanypodinae) and redescription of the male
}

\author{
Fabio Laurindo da Silva \& Alaide Aparecida Fonseca Gessner
}

\begin{abstract}
Laboratório de Entomologia Aquática, Departamento de Hidrobiologia, Centro de Ciências Biológicas e da Saúde, Universidade Federal de São Carlos. Rodovia Washington Luís, km 235, Caixa Postal 676, 13565-905 São Carlos, São Paulo, Brasil. E-mail: fabelha@hotmail.com
\end{abstract}

\begin{abstract}
The immature stages of Labrundinia tenata Roback, 1987 (Diptera: Chironomidae: Tanypodinae) are described and illustrated and the male is redescribed. Larvae were collected in aquatic systems in southeastern Brazil, where they are associated with aquatic macrophytes. The three semaphoronts of L. tenata are recognized: (a) Male by the abdominal segments I pale brown, II-VI with brown transverse band along proximal margin, VII, VIII almost wholly brown; hypopygium brown; anterior margin of sternapodeme rounded, no distinct spur. (b) Pupa by the thoracic horn S-shaped and a shallow preapical groove; abdominal segment VII with two lateral setae. (c) Larva with posteroventral spine group; posterior parapod with single elongate claw serrated on inner margin and numerous simple claws.
\end{abstract}

KEY WORDS. Brazil; neotropical; Pentaneurini; taxonomy.

The Pentaneurini genus Labrundinia was established by FITTKAU (1962), and L. longipalpis Goetghebuer, 1921 was designated as the type species. Currently, it includes 15 species, of which eight are Neotropical (Rоваск 1987a, EdWARds 1931), four Nearctic (Bеск \& Bеск 1966, Rоваск 1971), and one Palaearctic (FiтtкAu 1962). Labrundinia pilosella Beck \& Beck, 1966 and Labrundinia maculata Roback, 1971, originally described from Nearctic region, also occur in Neotropical region (SPIES \& ReIss 1996).

In Brazil, although Labrundinia spp. have been recorded in many ecological studies (Trivinho-Strixino \& Strixino 1993, Henriques-Oliveira et al. 2003, Siqueira \& Trivinho-Strixino 2005, Aburaya \& Callil 2007), yet they are poorly known taxonomically. Labrundinia tenata was described by Rоваск (1987a) from Colombia, based only on characters of the males and their immatures have thus far been unknown. In the present paper, the immatures stages of $L$. tenata are described and the male is redescribed in full detail. We present also information on the life-history of the species.

\section{MATERIAL AND METHODS}

Larvae were collected associated with aquatic macrophytes in small ponds from the state of São Paulo, Brazil and were reared in the laboratory to obtain pupae and adults as suggested by Mendes (2002). Specimens examined were slidemounted in Euparal, following the procedures outlined by PINDER $(1983,1986,1989)$.

Morphological terminology and abbreviations follow SÆTHER (1980), supplemented by KowALYK (1985) for larval cephalic setation, and Rоваск (1987a,b) for terminology relating to Labrundinia. The following additional abbreviations are used in text: (ALR) anal lobe ratio, (AMD) larval antennal segment I/mandible length, (APR) larval antennal segment I/basal palp segment length, (GcR) gonocoxite ratio, (IO) inner teeth of ligula/outer teeth length, (MO) median teeth of ligula/outer teeth length, (PR) larval basal palp segment ratio, (PTH) preapical papilla/thoracic horn length, (THR) thoracic horn ratio. Ratio equals to length divided by width of structure in question. Preapical papilla corresponds to membranous projection present apically on thoracic horn of pupa.

Measurements are given as the range followed by the mean with the number of observed specimens in parenthesis if it differs from the number (n) stated at the beginning of the description. Seta counts are given only as the range. Humerals were incorporated into the dorsocentrals.

The material examined is deposited in the Reference Collection of Laboratório de Entomologia Aquática, Universidade Federal de São Carlos. One male with associated pupal and larval exuviae will be deposited in the Museu de Zoologia da Universidade de São Paulo, São Paulo, Brazil (MZUSP).

\section{TAXONOMY}

Labrundinia tenata Roback, 1987

Figs 1-27

Material examined. Brazil, state of São Paulo, São Carlos, Fazzari reservoir, 04.V.2007, one male with associated pupal and larval exuviae, F.L. Silva leg.; as previous except for 14.V.2008; as previous except for 22.V.2008; as previous except for Espraiado reservoir, VI.1998, two larvae, S. Trivinho-Strixino leg.; as previous except for Itaqueri stream, 07.III.2008, one larva, C. C. Andrade leg. 
Diagnostic characters. Labrundinia tenata can be separated from others species of the genus by the following combination of characters: male with abdominal segments I pale brown, IIVI with brown transverse band along proximal margin, VII, VIII almost wholly brown; hypopygium brown; anterior margin of sternapodeme rounded, no distinct spur. Pupa with thoracic horn S-shaped and a shallow preapical groove with cleft in upper margin; abdominal segment VII with two lateral setae. Larva with posteroventral spine group, lateroventral spine group indistinct; posterior parapod with single elongate claw serrated on inner margin and numerous simple claws.

Male ( $\mathrm{n}=3$ unless otherwise stated). Dimensions. Total length 1.85-1.99, $1.94 \mathrm{~mm}$. Wing length 1.14-1.15, $1.14 \mathrm{~mm}$. Total length/wing length 1.63-1.75, 1.70. Wing length/length of profemur 2.4-3.2, 2.9. Coloration. Head pale brown with dark brown occipital margin. Antenna brown. Thorax pale brown with brown strips as in figure 3 . Wing clear with veins pale brown, without spots. Legs pale. Fore, mid and hind femur pale yellow. Fore tibia pale brown, mid and hind tibiae pale yellow. All fore tarsomeres pale brown and mid and hind tarsomeres pale yellow. Abdomen pale brown with maculation as in figure 11; tergite IX with brown distal margin. Hypopygium brown. Head (Figs 1 and 2). AR 1.03-1.22, 1.12; flagellum 600$657,632 \mu \mathrm{m}$ long. Temporal setae 10-12. Eyes ratio 1.4-1.9, 1.7. Clypeus with 12-13 setae. Tentorium 128-137, $131 \mu \mathrm{m}$ long. Palpomere lengths 1-5 (in $\mu \mathrm{m}$ ): 31 (1); 54 (1); 88 (1), 131 (1); 209 (1). Thorax. Antepronotum with 2-3 (2) setae. Acrostichals 24-27, biserial, all starting close to the anterior end; dorsocentrals 16-18, biserial anteriorly; prealars 5. Scutellum with 67 setae across disc and numerous fine anterior setae. Wing (Fig. 4) $0.33-0.34,0.33 \mathrm{~mm}$ wide. Costa not past $R_{4+5}$, ending very slightly beyond tip of $\mathrm{M}_{3+4}$. Base of radial sector 0.08-0.10, 0.09 $\mathrm{mm}$. VR 0.75-0.79, 0.76. Legs (Figs 5-10). Fore tibia with single pectinate spur, 13-15, $14 \mu \mathrm{m}$ long with three teeth; mid tibia with single pectinate spur, 12-14, $13 \mu \mathrm{m}$ long with three teeth. Width at apex of fore tibia 34-35, 34, mid tibia 29-32, 31, hind tibia 32-35, $33 \mu \mathrm{m}$ wide. Hind tibial comb with 6-7 setae. Mid leg with two pseudospurs on $\mathrm{Ta}_{1-4}$. Tarsal claws slender, hook shaped as in figure 10. Pulvillus absent. Length and proportion of legs as in table I. Hypopygium (Fig. 12). Tergite IX arched with 7-8 dorsal setae. Anterior margin of sternapodeme slightly rounded, no distinct spur. Phallapodeme 45-51, $49 \mu \mathrm{m}$ long.
Gonocoxite 98-109, $103 \mu \mathrm{m}$ long, 43-54, $48 \mu \mathrm{m}$ wide. GcR 2.032.30, 2.16. Gonostylus 62-65, $63 \mu \mathrm{m}$ long; megaseta 11-12, 11 $\mu \mathrm{m}$ long. HR 1.50-1.74, 1.63. HV 2.90-3.19, 3.09. Apical hairs of gonocoxite not numerous.

Pupa ( $n=3$ unless otherwise stated). Coloration. Cephalothorax and abdominal segments with pigmentation pale brown. Thoracic horn brown.

Cephalothorax (Figs 13-15). Frontal apotome as in figure 13. Wing sheath $0.73-0.76,0.75 \mathrm{~mm}$ long. Thoracic horn Sshaped, 203-228, $214 \mu \mathrm{m}$ long, $65 \mu \mathrm{m}$ wide, THR 3.14-3.52, 3.31, reticulation of respiratory atrium indistinct, external membrane with pale spinules basally concentrated, membranous preapical papilla 38-40, $39 \mu \mathrm{m}$, PTH 0.17-0.20, 0.18, aeropyle tube simple 13-18, $15 \mu \mathrm{m}$ long, plastron plate much reduced. Basal lobe short. Thoracic comb with 10-12 conical teeth. Abdomen. (Figs 16-19) 1.67-1.68, $1.68 \mathrm{~mm}$ long. Tergite I with elongate scar, without shagreen, sternites II-VII with shagreen apparently concentrated on basal and lateral margins. Chaetotaxy of abdomen as in figures 16-18. Segment VII with two lateral setae, Segment VIII with five lateral setae. Anal lobe $250 \mu \mathrm{m}$ long, with two lateral setae, outer margins with 7-10 spines, longest spine 9-11, $10 \mu \mathrm{m}$ long, membranous inner margins. ALR 1.34-1.38, 1.36. Genital sac elongate, longer than anal lobe.

Forth instar larva ( $\mathrm{n}=3$ unless otherwise stated). Coloration. Body pale yellow. Head pale yellow with postoccipital margin brown; antennal segment II pale brown; mandibular distal tooth and apex of ligula brown. Procercus and anal setae pale brown. Posterior parapod claws all pale yellow. Head (Fig. 20) 456-494, $473 \mu \mathrm{m}$ long, 331-388 (2) $\mu \mathrm{m}$ wide, slender almost rectangular; lateroventral spine group indistinct, posteroventral spine group present; cephalic index 0.73-0.78 (2). Chaetotaxy as in figure 18. Antenna (Figs 21 and 22) 295-317, $304 \mu \mathrm{m}$ long, basal antennal segment 192-208, $199 \mu \mathrm{m}$ long, with ring organ 169$188,176 \mu \mathrm{m}$ from base, antennal segment II 95-100, $97 \mu \mathrm{m}$ long. AR 1.78-2.05, 1.91. Blade longer than antennal segment II. Maxilla. Basal palp segment 26-31, $29 \mu \mathrm{m}$ long, 6-8, $7 \mu \mathrm{m}$ wide, with ring organ 17-23, $20 \mu \mathrm{m}$ from base. PR 3.9-4.3, 4.1. APR 6.3-7.6, 7.0. Mandible (Fig. 23) 69-76, $72 \mu \mathrm{m}$ long, with three lateral setae, strongly curved. Campaniform sensilium 51-55, 52 $\mu \mathrm{m}$ from apex. Basal tooth bifid, with seta subdentalis projecting from sloping end towards apical tooth. AMD 2.7-2.9, 2.8. Mentum (Fig. 24). Dorsomental teeth reduced and pseudoradula

Table I. Lengths (in $\mu \mathrm{m}$ ) and proportions of legs of L. tenata, male.

\begin{tabular}{|c|c|c|c|c|c|c|c|c|c|}
\hline fe & ti & ta1 & ta2 & ta3 & ta4 & ta5 & LR & BV & SV \\
\hline p1 $\begin{array}{l}356-469, \\
417\end{array}$ & $\begin{array}{l}381-406 \\
392\end{array}$ & $319(2)$ & $143(2)$ & $131(2)$ & $94-100(2)$ & $56-69(2)$ & $0.78-0.82(2)$ & $2.62-2.72(2)$ & $2.55-2.74(2)$ \\
\hline p2 $\begin{array}{l}431-450, \\
444\end{array}$ & $\begin{array}{l}406-413, \\
408\end{array}$ & $\begin{array}{l}475-531 \\
498\end{array}$ & $\begin{array}{l}225-231 \\
227\end{array}$ & $\begin{array}{l}\text { 119-125, } \\
121\end{array}$ & $\begin{array}{l}81-88, \\
83\end{array}$ & $\begin{array}{l}63-81 \\
77\end{array}$ & $\begin{array}{l}1.15-1.30 \\
1.22\end{array}$ & $\begin{array}{l}2.62-2.68, \\
2.66\end{array}$ & $\begin{array}{l}1.61-172, \\
1.72\end{array}$ \\
\hline p3 $\begin{array}{l}450-494, \\
473\end{array}$ & $\begin{array}{l}419-581, \\
515\end{array}$ & $\begin{array}{l}513-563, \\
538\end{array}$ & $206-225(2)$ & $131-150(2)$ & $100-119$ (2) & $63-69(2)$ & $0.94-0.96(2)$ & $2.84-3.06(2)$ & $1.84-1.99$ (2) \\
\hline
\end{tabular}



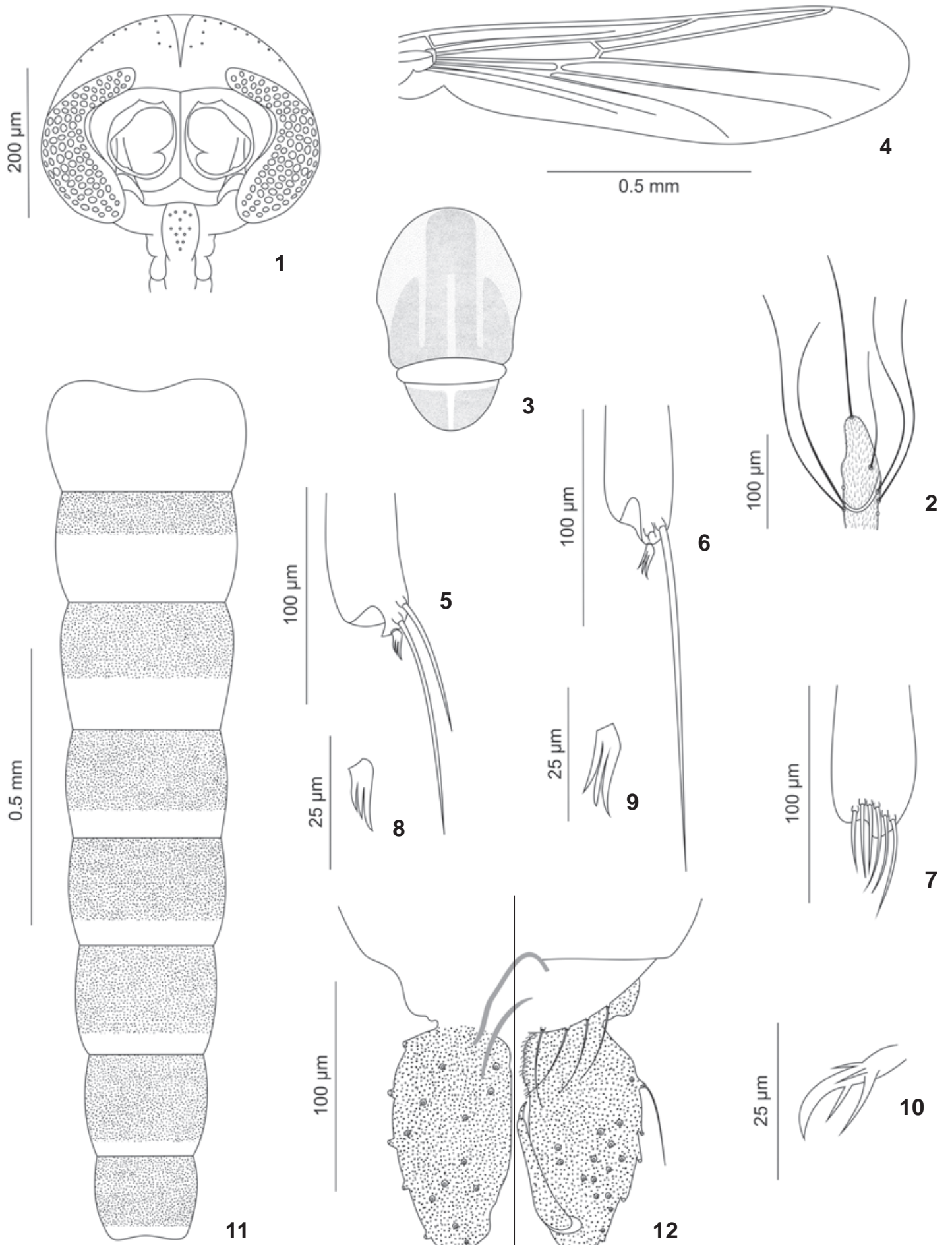

11
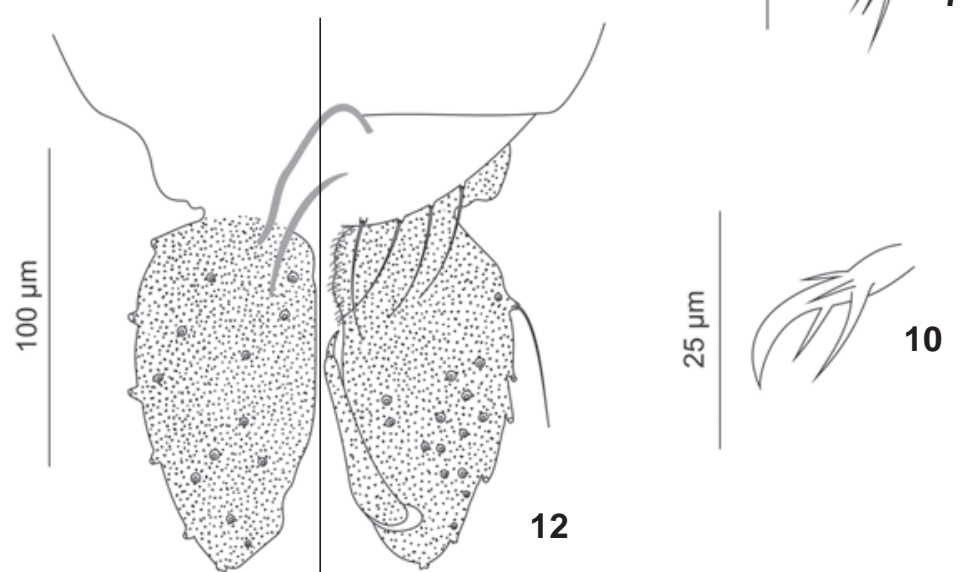

Figures 1-12. Labrundinia tenata, male: (1) head, dorsal view; (2) apex of Antenna. 3. thorax; (4) wing; (5) apex of fore tibia; (6) apex of mid tibia; (7) apex of hind tibia with comb; (8) fore spur; (9) mid spur; (10) hind tarsal claw; (11) abdomen coloration, dorsal aspect; (12) hypopygium, left: ventral aspect, right: dorsal aspect. 

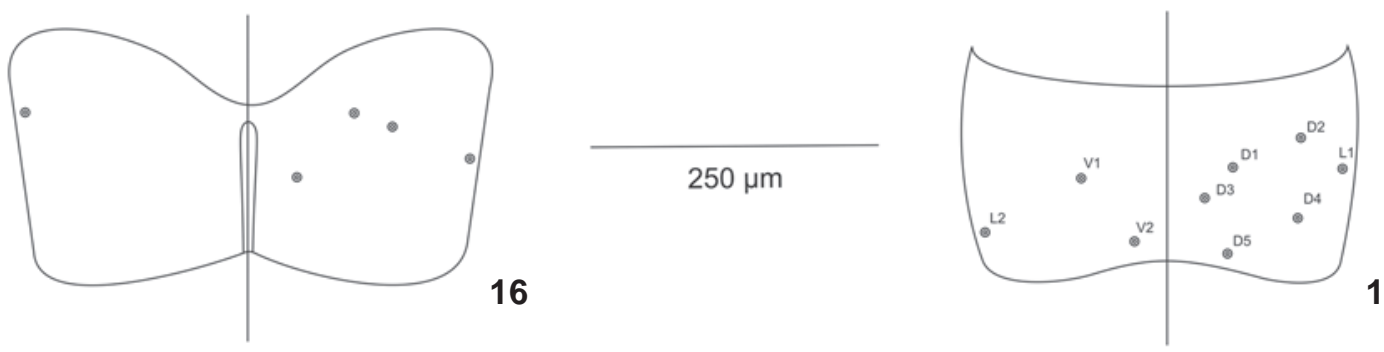

17
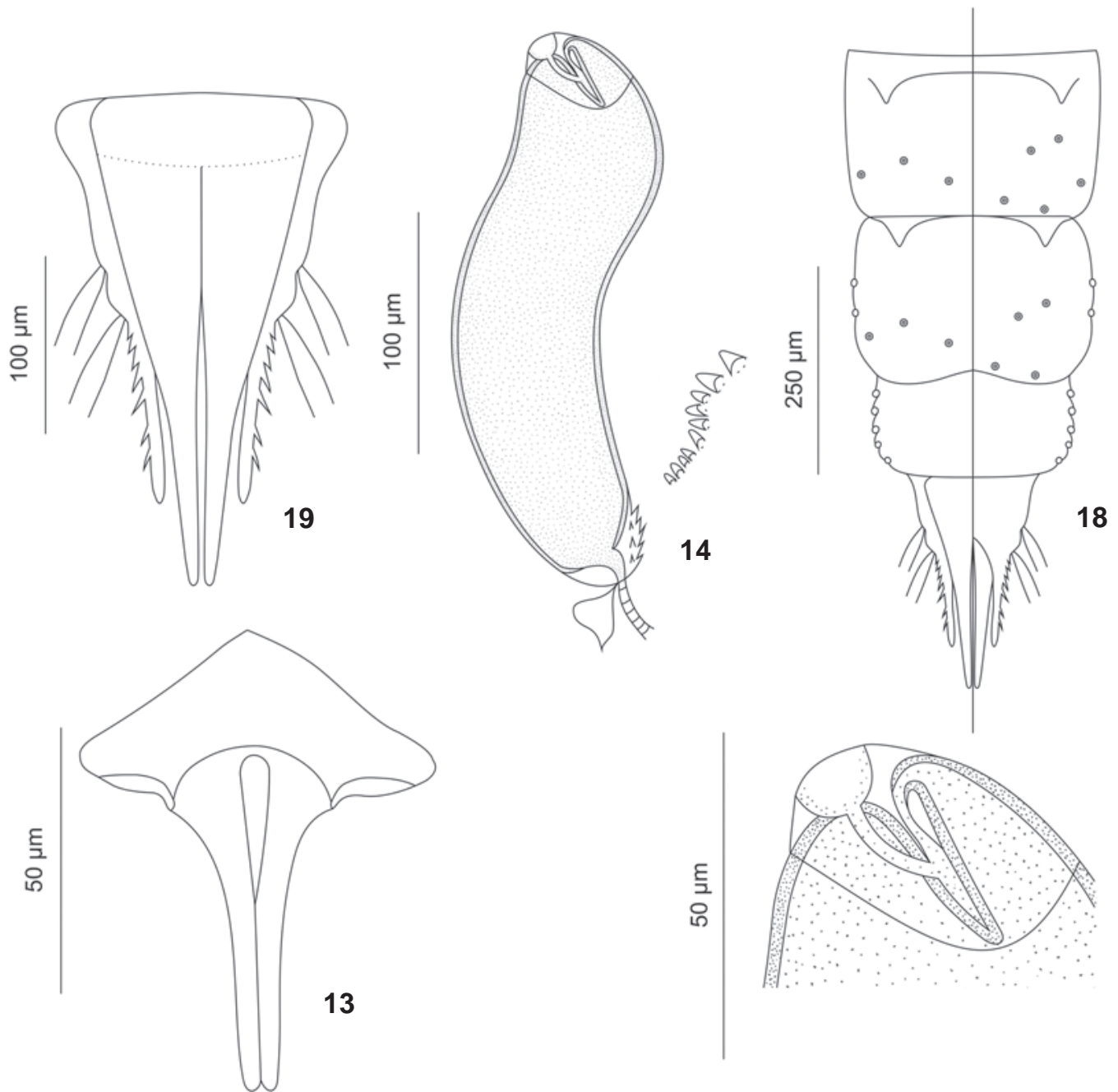

15

Figures 13-19. Labrundinia tenata, pupa: (13) frontal apotome; (14) thoracic horn with basal lobe and medial row of teeth; (15) apex of thoracic horn showing preapical papilla; (16-18) abdominal segments I, IV and VI-VIII respectively, left: ventral aspect, right: dorsal aspect; (19) anal lobe and genital sac, ventral aspect.

uniformly granulate. Hypopharyngeal complex (Figs 23 and 24). Ligula 57-59, $58 \mu \mathrm{m}$ long, 25-28, $26 \mu \mathrm{m}$ wide, with row of 5 teeth. IO 0.90-0.93, 0.91, MO 1.00-1.04, 1.02. Paraligula bifid, 22-23, $23 \mu \mathrm{m}$ long, inner tooth 18-19, $19 \mu \mathrm{m}$ long, shorter than outer tooth. Pectin hypopharyngis with six teeth almost equal sized. Abdomen (Figs 27-29). Without lateral fringe. Procercus 4.4-6.7, 5.5 times as long as wide, with seven 254-398, $342 \mu \mathrm{m}$ long anal setae. Anal tubules 145-158, $150 \mu \mathrm{m}$ long. Posterior 

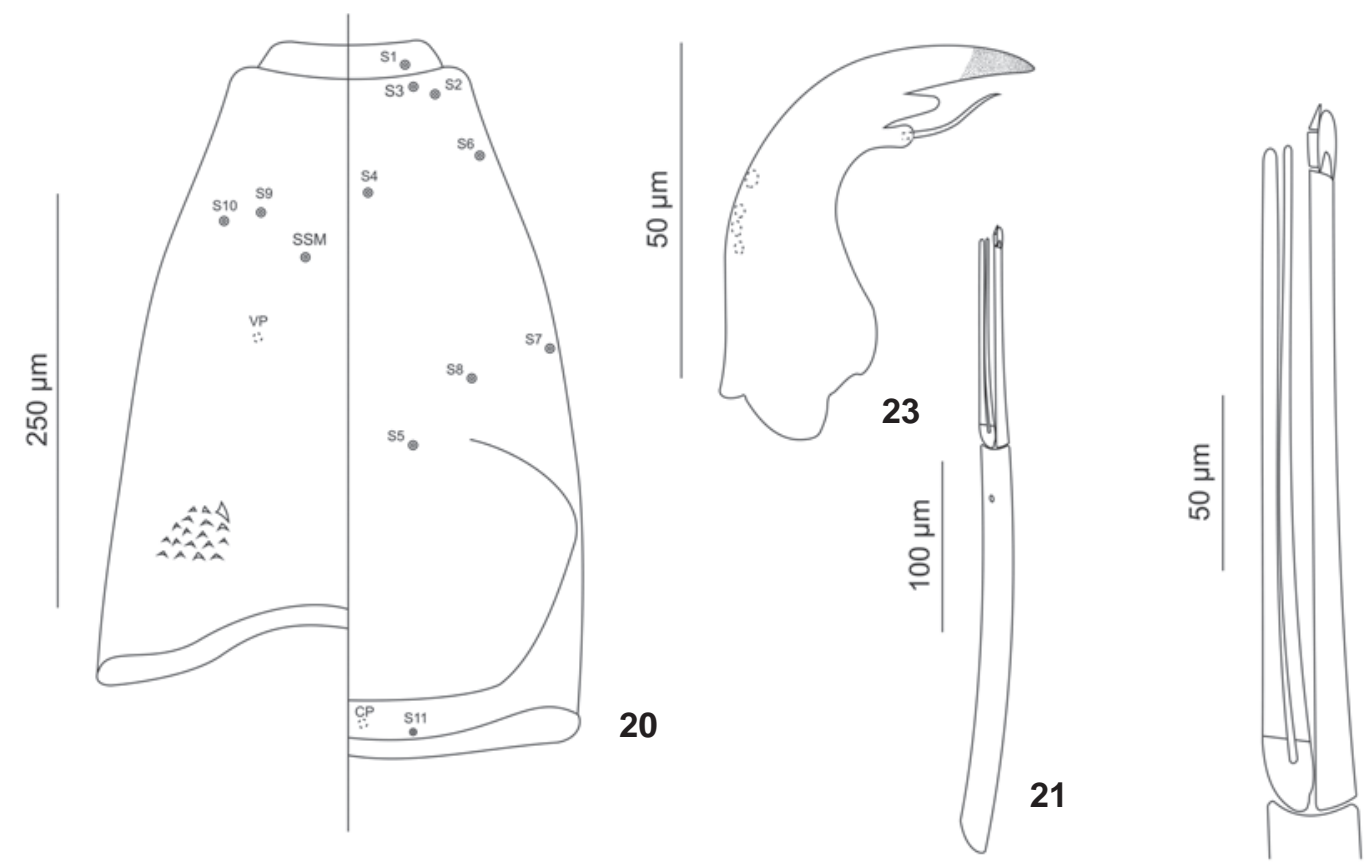

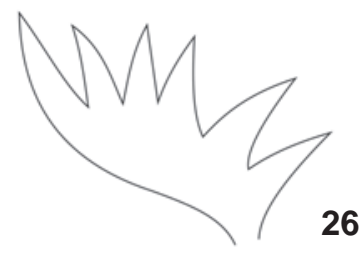

$25 \mu \mathrm{m}$

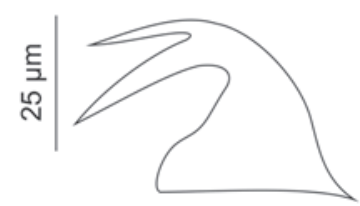

28

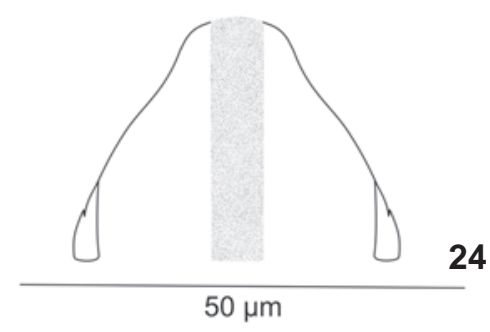

25
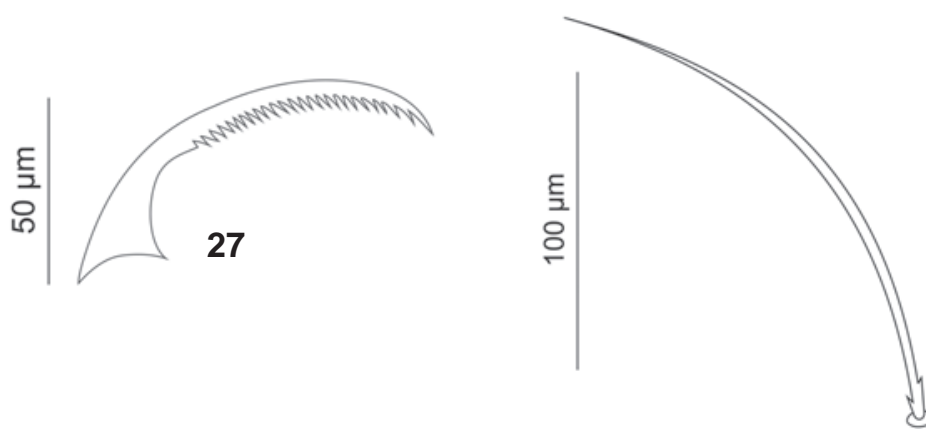

Figures 20-29. Labrundinia tenata, larva: (20) head, left: ventral aspect, right: dorsal aspect, showing posteroventral spine group and distribution of cephalic setae and pores; (21) antenna; (22) apex of antenna; (23) mandible; (24) mentum; (25) ligula and paraligula; (26) pectin hypopharyngis; (27) serrated claw; (28) bifid claw; (29) subbasal seta.

parapod 192-211 (2) $\mu \mathrm{m}$ long, with single elongate claw serrated on inner margin and numerous simple claws; bifid claw with Ushaped lower groove, subbasal seta simple with two teeth near base.
Remarks. The measurements obtained in this work for adult males are similar to those reported by Rоваск (1987a), with exception to leg lengths that presented wide variation. The coloration pattern of the abdominal segments II-VI allows 
separate the males of $L$. tenata of $L$. becki and $L$. parabecki that also have brown hypopygium, however the abdomen of these species is wholly darkened. Some specimens of L. pilosella also have brown hypopygium, but they differ of L. tenata by abdominal coloration pattern exhibited by segments III and V that are totally darkened.

The deep of apical groove and the short aeropyle tube distinguish the pupa of L. tenata of L. neopilosella that practically not present an apical groove and has an elongated aeropyle tube. The combination of the characters cephalic capsule with posteroventral spine group and absence of lateroventral spine group allow separate the larva of L. tenata of L. neopilosella that has evident lateroventral spine group.

The larvae of Labrundinia tenata were collected associated with aquatic macrophytes of the genus Salvinia in the Fazzari reservoir, which is located in a protected area in the city of São Carlos, in the campus of Universidade Federal de São Carlos, surrounded by cerrado fragment with low level of anthropic impact. This system is shallow (0.60 $\mathrm{m}$ depth), with acid water ( $\mathrm{pH}$ 6.8), high level of dissolved oxygen (9.4 mg..-1), low conductivity $\left(8 \mu \mathrm{S} . \mathrm{cm}^{-1}\right)$ and temperature ranging from $19-23^{\circ} \mathrm{C}$.

The larvae of Labrundinia are considered predators (COFFMAn \& FERRINGTON 1996), feeding on small invertebrates, including other Chironomidae larvae. In this work, the larvae of $L$. tenata analyzed exhibited basically detritus in their digestive tracts, which shows a diversity of habits for the genus as indicated by Henriques-Oliveira et al. (2003).

The female remains unknown.

\section{ACKNOWLEDGEMENTS}

The authors extend their thanks to Susana T. Strixino and Sofia Wiedenbrug for valuable suggestions. A special thanks to Juliano F. Nunes. F.L. Silva received financial support from the State of São Paulo Research Foundation (FAPESP proc. 2007/ 52900-4) within the BIOTA/FAPESP - The Biodiversity Virtual Institute Program (www.biota.org.br). Financial support was also given by the Programa de Pós-Graduação em Ecologia e Recursos Naturais da Universidade Federal de São Carlos (CAPES-DS).

\section{LITERATURE CITED}

Aburaya, F.H. \& C.T. Callil. 2007. Variação temporal de Chironomidae (Diptera) no Alto Rio Paraguai (Cáceres, Mato Grosso, Brasil). Revista Brasileira de Zoologia 24 (3): 565-572.

BeCK, W.M. \& E.C. Bеск. 1966. Chironomidae (Diptera) of Florida. I. Pentaneurini (Tanypodinae). Bulletin of the Florida State Museum. Biological Sciences 10: 305-379.

Coffman, W. P. \& L.C. Ferrington. 1996. Chironomidae, p. 635754. In: R. Merrit \& K. Cummins (Eds). An introduction to the aquatic insects of North America. Dubuque, Kendall
Hunt, $3^{\text {rd }}$ ed. 722 p.

Edwards, F.W. 1931. Diptera of Patagonia and South Chile II Chironomidae. Trustees of the British Museum (Natural History) 5: 233-331.

FrTTKAU, E.J. 1962. Die Tanypodinae (Diptera: Chironomidae). (Die tribus Anatopyniini, Macropelopiini und Pentaneurini). Abhandlungen zur Larvalsystematik der Insekten 6: 1-453.

KowaLYK, H.E. 1985. The larval cephalic setae in the Tanypodinae (Diptera: Chironomidae) and their importance in generic determinations. Canadian Entomologist 117: 67-106.

Henriques-Oliveira, A.L.; J.L. Nessimian \& L.F.M. Dorvillé. 2003. Feeding habitats of chironomid larvae (Insecta: Diptera) from a stream in the Floresta da Tijuca. Brazilian Journal of Biology 63 (2): 269-281.

Mendes, H.F. 2002. Rearing Tanypodinae, Telmatogetoninae and Orthocladiinae in Brazil - an empirical approach. Chironomus Newsletter 15: 29-32.

PINDER, L.C.V. 1983. The larvae of Chironomidae (Diptera) of the Holartic region - Introduction. Entomologia Scandinavica Supplement 19: 7-10.

Pinder, L.C.V. 1986. The pupae of Chironomidae (Diptera) of the Holartic region - Introduction. Entomologia Scandinavica Supplement 28: 5-7.

Pinder, L.C.V. 1989. The adult of Chironomidae (Diptera) of the Holartic region - Introduction. Entomologia Scandinavica Supplement 34: 5-9.

Rоваск, S.S. 1971. The adults of the subfamily Tanypodinae (= Pelopiinae) in North America (Diptera: Chironomidae). The Academy of Natural Sciences of Philadelphia 19th and the Parkway Philadelphia 17: 1-410.

RoвACK, S.S. 1987a. New species of Labrundinia from Colombia (Diptera: Chironomidae: Tanypodinae). Proceedings of the Academy of Natural Sciences of Philadelphia 139: 211-222.

Rоваск, S. S. 1987b. The immature chironomids of the eastern United States. IX. Pentaneurini -Genus Labrundinia with the description of some Neotropical material. Proceedings of the Academy of Natural Sciences of Philadelphia 139: 159-209.

SÆTHER, O.A. 1980. Glossary of chironomid morphology terminology (Diptera: Chironomidae). Entomologica Scandinavica Supplements 14: 1-51.

Siqueira, T. \& S. Trivinho-Strixino. 2005. Diversidade de Chironomidae (Diptera) em dois córregos de baixa ordem na região central do Estado de São Paulo, através da coleta de exúvias de pupa. Revista Brasileira de Entomologia 49 (4): 531-534.

Spies, M. \& F. Reiss. 1996. Catalog and bibliography of Neotropical and Mexican Chironomidae (Insecta, Diptera). Spixiana Supplement 22: 61-119.

Trivinho-Strixino, S. \& G. Strixino. 1993. Estrutura da comunidade de insetos aquáticos associados à Pontederia lanceolata Nuttal. Revista Brasileira de Biologia 53 (1): 103-111.

Submitted: 22.X.2008; Accepted: 07.IX.2009.

Editorial responsibility: José Albertino Rafael

ZOOLOGIA 26 (3): 541-546, September, 2009 